\title{
The Benefits of Regular Physical Activity on Hearing in Visually Impaired Adolescents
}

\author{
Serap Yildirim¹, Ramazan Yuksel ${ }^{2}$, Songul Doganay ${ }^{1}$, Mustafa Gul ${ }^{1}$, Fatih Bingol ${ }^{3}$, Senol Dane ${ }^{4}$
}

${ }^{1}$ Department of Physiology, Medical School, Ataturk University, Erzurum, Turkey

${ }^{2}$ Department of Physiology, Medical School, Yildirim Beyazit University, Ankara, Turkey

${ }^{3}$ Deparment of Otorhinolaryngology, Erzurum Regional Training and Research Hospital, Erzurum, Turkey

${ }^{4}$ Department of Physiology, Medical School, Turgut Ozal University Ankara, Turkey

Eur J Basic Med Sci 2013;3(1): 17-21

Received: 27-03-2013

Accepted: 15-05-2013

Correspondence (Yazıșma Adresi):

Dr. Ramazan YÜKSEL, School of

Medicine, Department of Medical

Physiology, Yıldırım Beyazıt University,

Ankara, Turkey

e-mail: ryuksel38@hotmail.com

\begin{abstract}
The aim of this study was to investigate the possible beneficial effects of regular physical activity on auditory reaction time and the duration of hearing in congenital visually impaired adolescents by examining some auditory performances involving perception and motor components. Forty visually impaired and 30 sighted-control adolescents, 10 to 22 years old (14.04 \pm 2.77$)$ participated in the study. All 40 visually impaired adolescents, 13 were goalball players and 27 were sedentary. To measure the duration of hearing, an index of auditory acuity, a tuning fork of $256 \mathrm{~Hz}$, and a digital chronometer were used. Auditory reaction time (msec.) was longer in visually impaired adolescents compared to sighted controls for both right and left-hands (right: $t=3.95$, $p=0.00$; left: $t=3.66, p=0.00$ ). The visually impaired adolescents had the increased reaction time and the decreased duration of hearing, or disadvantages for both auditory reaction time and duration of hearing. Auditory reaction speed and duration of hearing was decreased in sedentary visually impaired adolescents than in visually impaired goalball players. These results suggest that playing goalball designed for the blind is very beneficial to decrease their neuropsychological and developmental problems.
\end{abstract}

Key Words: Visually impaired adolescents, regular physical activity, reaction time, duration of hearing

Görme Engelli Adolesanlarda Düzenli Fiziksel Aktivitenin Ișitmeye Katkısı

\section{ÖZET}

Bu çalıșmanın amacı, gençlerde algı ve motor bileșenleri içeren bazı ișitsel performansları inceleyerek düzenli fiziksel aktivitenin konjenital görme engelli çocuklarda işitsel reaksiyon zamanı ve ișitme süresi üzerine olası yararlı etkilerini araștırmaktır. Çalıșmaya yaşları 10 ile 22 arasında değișen (14.04 \pm 2.77) 40 görme engelli ve 30 görme engeli olmayan genç dahil edildi. 40 kișilk görme engelli grubun 13'ü goalball oyuncusu ve 27'si sedanterdi. Ișitme süresini ölçmek için, ișitme keskinliğinin bir göstergesi olarak 256 Hz'lik diyapozon, ve bir dijital kronometre kullanıldı. Ișitsel reaksiyon zamanı (msn) görme engelli gençlerde kontrol grubuna göre her iki elde de daha uzundu (sağ el=3.95, $p=0.00$; sol el=3.66, $p=0.00$ ). Görme engelli çocuklarda reaksiyon zamanı uzun 
ve işitme süresi kısaydı. Ișitsel reaksiyon hızı ve ișitme süresi görme engelli sedanterlerde goalball oyuncularına kıyasla daha kısaydı. Bu sonuçlar görme engelliler için tasarlanan goalball sporunun nöropsikolojik ve gelișimsel problemleri azaltmada çok yararlı olduğunu göstermektedir.

Anahtar kelimeler: Görme engelli adolesanlar, düzenli fiziksel aktivite, reaksiyon zamanı, ișitme süresi

\section{INTRODUCTION}

Behavioral impact of physical activity have reported significant interventions in many studies. Blindness is a physical disability, causing the lower physical work, and leading to posture problems, orientation difficulties, depression and balance problems (1). There are many people with the problem of visually impaired neuropsychological development. Therefore, adolescents with visual impairment need more psychological and physical support. Health-related outputs are poorer in visually impaired adolescents compared to those with normal vision (2). Because of the diminished physical activity, cardiovascular endurance, muscular endurance and flexibility, and balance were lower in individuals with visual impairments compared to non-impaired sights (3). People with visual impairment are more obese than sighted people and the lower aerobic capacity and obesity may be partly attributable to a lack of habitual physical activity (4). Exercise is the most important factor for a healthy body and brain. A meta-analysis reported a positive correlation between physical activity and learning and intelligence scores in school-age children (5). In a recent study, Akarsu et al. (6) reported that athletes had the lower reaction time (the faster) and the higher visuo-spatial intelligence compared to non-athletes. In addition, reaction time (7) and vocabulary learning were faster immediately after intense running (8). In a new review study, it has been suggested that exercise is an important and strong stimulus for neurogenesis and vasculogenesis (9). Wheel running exercise in laboratory animals increases cell proliferation in the dentate gyrus of the hippocampus (10). Also, the running exercise increases dendritic spine density in the dentate gyrus (11). It can be stated that physical exercise is need for adaptation to life and the environment. Therefore, physical fitness is closely related to one's health, the quality of life, the effectiveness of learning and working, participation in physical exercises (12). Earlier studies reported that sport or exercise is beneficial for those who have blindness or visual impairment (12). Goalball is a team sport designed specifically for blind athletes as a means of assisting the rehabilitation of visually impaired veterans in 1946 . Goalball is played by two teams of three players, and the games consist of two 12-minute halves. The players try to throw a ball that has bells embedded in it into the opponents' goal. Therefore, the sound of the bell is used to judge the position and movement of the ball (1).

In a previous study, it has been reported that goalball playing was significant factor influencing auditory reaction time and suggested that it was a very beneficial for brain maturation in visually impaired adolescents (13). Also, it has been reported that physical fitness of visually impaired goalball players was higher than that of sedentary adolescents and suggested that visually impaired adolescents to participation sports or recreational activities such as goalball has importance in improving their physical fitness (14). In the present study, we investigated the possible benefits of regular physical activity in visually impaired adolescents compared to peer sighted ones. For this purpose, auditory reaction time and duration of hearing were used in blind goalball players and sighted adolescents.

\section{MATERIAL and METHODS}

The Ethical Committee of the Faculty of Medicine of the University of Fatih approved this study. All subjects were considered for involvement after they have informed about the study. Participants were 40 visually impaired and 30 control adolescents, 10 to 22 years old $(M=14.04$, $S D=2.77)$. Of 40 visually impaired adolescents, 13 were goalball players and 27 were sedentary. Goalball players were playing goalball about two hours for every time, three times per week for two years regularly. To measure the duration of hearing, an index of auditory acuity, a tuning fork of $256 \mathrm{~Hz}$, and a digital chronometer were used. The impact of a calibrated force produced with a device used first by Dane and Bayirli (15) was applied to the tuning forks on the device and at the same time a chronometer was started. Then, the tuning forks were held at about $1 \mathrm{~cm}$ distant in front of the ear. Participants started both the device (the impact to tuning forks) and the chronometer at the same time by pressing a button, and, when they no longer heard the vibrations of tuning fork, they stopped the calibrated chronometer by pressing the same button on the device. Measurement was made 10 times for both ears. The highest and lowest values were removed and the mean of remainder 8 
Table 1. Means (M) and standard deviations (SD) of auditory reaction time (msec.) and duration of hearing (sec.) in sighted and visually impaired adolescents.

\begin{tabular}{|c|c|c|c|c|c|c|}
\hline \multirow[b]{2}{*}{ Auditory Reaction Time } & \multicolumn{2}{|c|}{ Sighted $(\mathrm{N}=30)$} & \multicolumn{3}{|c|}{ The visually impaired $(\mathrm{N}=40)$} & \multirow[b]{2}{*}{$\mathrm{p}$} \\
\hline & $M$ & SD & $M$ & SD & $\underline{t}$ & \\
\hline Right hand & 221.6 & 63.97 & 333.4 & 144.47 & 3.95 & 0.00 \\
\hline Left hand & 241.07 & 61.14 & 328.4 & 119.39 & 3.66 & 0.00 \\
\hline \multicolumn{7}{|l|}{ Duration of Hearing } \\
\hline Right ear & 87.79 & 18.86 & 74.61 & 26.24 & 2.33 & 0.02 \\
\hline Left ear & 81.23 & 18.17 & 69.12 & 27.31 & 2.11 & 0.03 \\
\hline
\end{tabular}

values was computed and accepted as duration of hearing. To measure auditory reaction time, New Test 2000 device and protocol were applied. The subject's elbow was fixed on a support and the device fixed on another support during the measurement. When auditory signal was heard, participants stopped by pressing a button on device. Auditory reaction time was measured 10 times for both hands. The highest and lowest values were removed and the mean of remainder 8 values was computed and accepted as auditory reaction time. Both measurements were applied in a room isolated from external sounds. The statistical software SPSS 11.0 for Windows was used for statistical analysis.

\section{RESULTS}

Auditory reaction time (msec.) was longer in visually impaired adolescents compared to sighted controls for both right- and left-hands (right: $t=3.95, p=0.00$; left: $t=3.66$, $\mathrm{p}=0.00$ ). Duration of hearing (sec.) was decreased in visually impaired adolescents than in sighted adolescents for both right- and left-ear (right: $t=2.33, p=0.02$; left: $\mathrm{t}=2.11, \mathrm{p}=0.03$ ) (see Table 1). According to these data, auditory reaction speed was slower and duration of hearing was shorter in the blind than sighted ones. Auditory reaction time (msec.) was longer in sedentary visually impaired adolescents compared to goalball players with blindness for both right- and left-hands (right: $t=3.41$, $\mathrm{p}=0.002$; left: $t=3.95, \mathrm{p}=0.00$ ). Duration of hearing (sec.) was decreased in sedentary visually impaired adolescents than in goalball players with blindness for both right- and left-ear (right: $t=2.33, p=0.02$; left: $t=2.11, p=0.03$ ) (see Table 2). According to these results, auditory reaction speed was slower and duration of hearing was shorter in the sedentary blind than goalball players with blindness. Multivariate analysis of variance indicated that goalball playing was significant factor influencing the auditory reaction time and the duration of hearing $(F=5.76, p=0.00$, $\mathrm{ES}=0.27$ ) but not gender and age.

\section{DISCUSSION}

In the present study, the visually impaired adolescents had disadvantages for both auditory reaction time and duration of hearing. Also, auditory reaction time was longer in sedentary blind adolescents compared to goalball players with blindness for both right- and left-hands. This means that auditory reaction speed was slower in the blind. Duration of hearing was decreased in sedentary visually impaired adolescents than in goalball players with blindness for both right- and left-ear. These results were consistent with the studies performed by Caliskan (13) and Karakaya et al. (14). For blind individuals, audition provides critical information about the

Table 2. Means and standard deviations of auditory reaction time (msec.) and duration of hearing (sec.) in visually impaired goalball players and sedentary blinds.

\begin{tabular}{|c|c|c|c|c|c|c|}
\hline \multirow{2}{*}{ Auditory Reaction Time } & \multicolumn{2}{|c|}{ Goalball players $(\mathrm{N}=13)$} & \multicolumn{4}{|c|}{ Sedentary blinds $(\mathrm{N}=27)$} \\
\hline & $M$ & SD & $M$ & SD & $t$ & $p$ \\
\hline Right hand & 233.92 & 69.48 & 381.29 & 147.47 & $\overline{3.41}$ & 0.002 \\
\hline Left hand & 236.77 & 65.26 & 372.52 & 114.82 & 3.95 & 0.00 \\
\hline \multicolumn{7}{|l|}{ Duration of Hearing } \\
\hline Right ear & 101.02 & 11.72 & 61.81 & 21.12 & 6.25 & 0.00 \\
\hline Left ear & 96.05 & 13.85 & 56.15 & 22.21 & 5.92 & 0.00 \\
\hline
\end{tabular}


environment. Especially early blinded individuals show enhanced auditory abilities relative to sighted controls as measured by tasks requiring complex discrimination, attention and memory. But, some deficits have been also reported on tasks involving auditory sensory thresholds $(16,17)$. In latter study, 18 normally hearing blind and 18 matched normal-sighted students were compared with regard to differential auditory sensitivity and acoustic reflex thresholds. There was no difference for interaural time differences for directional hearing and acoustic reflex thresholds between the blind and sighted groups and therefore any superior hearing of the blind was not mirrored by a corresponding superiority in peripheral supraliminal performance (17). For another example, the gap detection abilities in the early blind using a singleinterval re-examined and estimates of gap detection thresholds for early blind subjects were nearly identical to sighted age matched controls and poorer relative to the younger sighted controls (18).

Meahcham et al. (19) reported that congenitally visually impaired adolescents have a delay for motor development. A recent study evaluating the effect of loss of hearing and vision on balance and gait showed that scores for the hearing impaired group were more like those of the control group than those of the visually impaired group and adolescents with visual impairment had more problems with balance and gait than controls (20). Navarro et al. (21) reported the visually impaired adolescents performed worse in tests evaluating balance and appendage coordination compared to normal sighted adolescents and suggested that visual deficiency impairs children's neuro-psychomotor development. In this study, auditory reaction speed was slower and duration of hearing was shorter in the blind than sighted ones; and in the sedentary blind than goalball players with blindness. These results may be associated with the neuropsychological problems in blinds such as diminished physical work, aerobic capacity, muscular and cardiovascular endurances and flexibility; posture, balance and orientation problems; and the higher depression and obesity risks (1$3)$. On the other hand duration of hearing was higher in goalball players with blindness than sighted ones remarkably. That is to say that physical activity is very important for perception and motor functions of the body. In that case regular physical activity is acquired a person many kind of skills. As a consequence, the visually impaired adolescents' neuro-psycho-motor and perceptual developments is poor and therefore they need physical exer- cise. Goalball sport must be recommended for all visually impaired adolescents.

\section{REFERENCES}

1. Colak T, Bamac B, Aydin M, Meric B, Ozbek A. Physical fitness levels of blind and visually impaired goalball team players. Isokine Exerc Sci 2004; 12: 247-52.

2. Lieberman LJ, McHugh E. Health-related fitness of children who are visually impaired. J Visu Impa Blin 2001; 95: 27287.

3. Skaggs S, Hopper C. Individuals with visual impairments: a review of psychomotor behavior. Adap Phys Acti Quart 1996; 13:16-26.

4. Hopkins WG, Gaeta H, Thomas AC, Hill PM. Physical fitness of blind and sighted children. Eur J App Phys Occup Phys 1987; 56: 69-73.

5. Sibley BA, Etnier JL. The relationship between physical activity and cognition in children: a meta-analysis. Ped Exer Sci 2003; 15: 243-56.

6. Akarsu S, Caliskan E, \& Dane S. Athletes have faster eyehand visual reaction times and higher scores on visuospatial intelligence than nonathletes. Turkish Journal of Medical Sciences 2009; 39(6): 871-4.

7. Hillman $\mathrm{CH}$, Snook EM, Jerome G J. Acute cardiovascular exercise and executive control function. Int J Psyc 2003; 48:307-14.

8. Winter B, Breitenstein C, Mooren FC, et al. High impact running improves learning. Neurobiol Learn Mem 2007; 87(4):597-609.

9. Van Praag H. Exercise and the brain: something to chew on. Trend Neur 2009; 32:283-90.

10. van Praag $\mathrm{H}$. Neurogenesis and exercise: past and future directions. Neur Med 2008; 10: 28-140.

11. Stranahan AM, Khalil D, Gould E. Running induces widespread structural alterations in the hippocampus and entorhinal cortex. Hippo 2007; 17: 1017-22.

12. Chen CC, Lin SY. The impact of rope jumping exercise on physical fitness of visually impaired students. Res Dev Disab 2011; 32:25-9.

13. Caliskan E. The effects of long term goalball sport on reaction times in blind children by sex and handedness. Neur Psyc B Res 2010; 16: 97-100. 
14. Karakaya IC, Aki E, Ergun N. Physical fitness of visually impaired adolescent goalball players. Perc M Skil 2009; 108:129-36.

15. Dane S, Bayirli M. Correlations between hand preference and durations of hearing for right and left ears in young healthy subjects. Perc M Ski 1998; 86: 667-72.

16. Yates JT, Johnson RM, Starz WJ. Loudness perception of the blind. Aud 1972; 11:368-76.

17. Starlinger I, Niemeyer W. Do the blind hear better? Investigations on auditory processing in congenital or early acquired blindness. I. Peripheral functions. Audiology 1981; 20: 503-9.
18. Weaver KE, Stevens AA. Auditory gap detection in the early blind. Hear Res 2006;211: 1-6.

19. Meahcham FR, Kline MM, Stovall JA. Adaptive behavior and low incidence handicaps: hearing and visual impairments. J Spec Edu 1987; 20:183-96.

20. Uysal SA, Erden Z, Akbayrak T. Comparison of balance and gait in visually or hearing impaired children. Perc M Ski 2010; 111: 71-80.

21. Navarro AS, Fukujima MM, Fontes SV, Matas SL, Prado GF. Balance and motor coordination are not fully developed in 7-year-old blind children. Arq Neu 2004; 62: 654-7. 